\title{
Evaluasi Profil Sensori Abon Ikan Jenis Pelagis Besar Menggunakan Metode Rate-All-That-Apply (RATA)
}

\section{Sensory Profile Evaluation of Shredded Large Pelagic Fish using Rate-All-That-Apply (RATA) Method}

\author{
Ni Made Inten Kusuma Dewi ${ }^{1}$, I Putu Suparthana ${ }^{{ }^{*}}$, I Desak Putu Kartika Pratiwi ${ }^{1}$ \\ Program Studi Teknologi Pangan, Fakultas Teknologi Pertanian, Universitas Udayana \\ Kampus Bukit Jimbaran, Badung-Bali \\ *Penulis korespondensi: IP Suparthana, email: suparthana@unud.ac.id
}

\begin{abstract}
This research aims to determine the sensory profile of commercial shredded large pelagic fish based on consumer acceptance and the intensity of sensory attributes that determine consumer preference using the Rate All That Apply (RATA) method. Six shredded products that were used as samples were tested in one sampling session by 65 panelists. This research was designed to create a sensory profile using principal component analysis (PCA) and analysis of variance (ANOVA) followed by the Duncan test, determining consumer preferences using Preference Mapping, and then making target market predictions using least square partial regression. The results showed that all products have similarities based on PCA but have different intensity based on ANOVA. The results of the preference mapping panelist analysis showed that Q products had the highest level of preference with the attributes favored by consumers such as sweet aroma and spices, fibrous and dry texture, and sweet taste.
\end{abstract}

Keywords: shredded large pelagic fish, sensory profile evaluation, rate-all-that-apply method

\section{PENDAHULUAN}

Indonesia merupakan negara pengekspor lebih dari 16\% produksi ikan pelagis besar (tuna, tongkol dan cakalang) dunia. Pada tahun 2018, volume ekspor mencapai sekitar 168,4 ribu ton dengan nilai USD 713,9 juta (BBPPPKP, 2019). Ukuran ikan tuna, tongkol, dan cakalang yang tidak sesuai dengan mutu ekspor sering dimanfaatkan oleh masyarakat Indonesia untuk diolah menjadi produk pangan siap saji. Salah satu olahan produk pangan dalam bentuk kering yang dibuat adalah abon.

Abon merupakan makanan kering berbentuk khas yang dibuat dari daging, direbus, disayatsayat, dibumbui, digoreng dan dipres (BPOM, 1995). Saat ini produk abon juga banyak dibuat berbahan dasar ikan laut seperti tuna, tongkol, dan cakalang. Produk abon memiliki umur simpan yang panjang dengan jangkauan distribusi yang luas sehingga pengusaha UMKM memilih produk tersebut untuk dijadikan usaha. Salah satunya pengusaha di Bali terutama daerah kota Denpasar dan kabupaten Badung yang memiliki pengusaha bidang makanan terbanyak di Bali.

Dinas Koperasi dan UMKM kabupaten Badung dan Kota Denpasar (2019) mencatat bahwa jumlah produsen abon ikan yang sudah memiliki izin p-irt sebanyak 6 usaha dimana usaha abon ikan yang terletak di daerah Badung sebanyak 2 usaha sedangkan daerah Denpasar sebanyak 4 usaha. Usaha rumahan abon ikan yang belum mencantumkan izin p-irt dan menjual produknya 
secara daring di daerah Badung dan Denpasar ada sekitar 6 usaha (Anon, 2020). Hal ini menyebabkan banyak pengusaha makanan mengeluarkan produk serupa dengan sensori yang mirip satu sama lainnya. Salah satu cara agar produsen produk abon ikan dapat bersaing dengan produk kompetitor lainnya dengan menghasilkan produk yang sesuai dengan keinginan konsumen. Informasi penerimaan konsumen terhadap suatu produk dapat dijadikan gambaran untuk mengetahui kelayakan produk, peningkatan kualitas, serta penentuan target pasar. Metode yang dapat digunakan untuk mendapatkan informasi tersebut adalah dengan uji sensori.

Uji sensori produk secara konvensional dilakukan dengan menggunakan panelis pencicip terbatas dan panelis terlatih dalam mendeskripsikan produk yang dilakukan di laboratorium. Panelis pencicip terbatas dan terlatih dapat mendiskriminasi produk secara akurat, namun membutuhkan waktu yang lebih lama dan harus dilatih secara terus menerus (Soewarno dan Soekarto, 1985). Pengujian dengan panelis konsumen juga diperlukan dalam pengembangan produk. Perbedaan uji ini dengan uji profil konvensional yakni uji ini dilakukan pada lingkungan yang apa adanya dan sesuai dengan kondisi saat konsumen menggunakan produk.

Salah satu uji profil sensori produk berbasis konsumen adalah metode Rate All That Apply (RATA) atau dikenal dengan Check All That Apply (CATA) with intensity (Reinbach et al., 2014). Metode RATA dapat memberikan data biner dan data intensitas untuk setiap atribut sehingga meningkatkan kemampuan diskriminasi antar sampel. Pengujian RATA yang disertai dengan uji rating hedonik tidak memberikan kesulitan secara signifikan kepada panelis konsumen sehingga data yang diperoleh tidak mengalami bias (Jaeger dan Ares, 2015).

Profil atribut sensori produk yang telah diketahui dan dikombinasikan dengan uji rating hedonik dapat membantu proses analisis dalam pengembangan produk serta membuat rancangan pemetaan konsumen. Adanya pemetaan konsumen akan mempermudah produsen dalam membuat analisis prediksi target pasar produk. Oleh karena itu penelitian ini bertujuan untuk mengetahui profil sensori abon ikan jenis pelagis besar berdasarkan persepsi panelis untuk memperoleh informasi dalam pembuatan peta kesukaan panelis serta prediksi target pasar abon ikan jenis pelagis besar.

\section{METODE PENELITIAN}

\section{Tempat dan Waktu Penelitian}

Penelitian ini dilakukan di Laboratorium Pengolahan program studi Teknologi Pangan, Fakultas Teknologi Pertanian Universitas Udayana, areal Universitas Udayana dan sekitar daerah Denpasar dan Badung selama bulan Agustus-Oktober 2020.

\section{Bahan dan Alat}

Bahan-bahan yang digunakan dalam penelitian ini adalah air mineral dan sampel abon ikan jenis pelagis besar yang diperoleh dari 6 produsen abon ikan yang terletak di kabupaten Badung dan kota Denpasar, yaitu dari daerah Kuta Selatan (1), Denpasar Utara (1), Denpasar Timur (1), Denpasar Selatan (2), dan Denpasar Barat (1). Total sampel abon ikan jenis pelagis besar yang 
terpilih sebanyak 6 jenis (kode sampel O, P, Q, R, $\mathrm{S}, \mathrm{T})$ dan berasal dari produsen yang sudah memiliki izin p-irt sebanyak 3 usaha dan produsen dari usaha rumahan yang belum memiliki izin $\mathrm{p}$-irt sebanyak 3 usaha.

Alat-alat yang digunakan dalam penelitian ini adalah kuisioner, timbangan digital, kertas label, nampan, piring kertas, sendok, plastik PP, toples, dan perangkat lunak untuk analisis data.

\section{Pelaksanaan Penelitian}

Pelaksanaan penelitian dilakukan dalam empat tahap dimulai dari focus group discussion (FGD), tahap skrining panelis, tahap pengujian sampel, dan analisis data.

\section{Focus Group Discussion (FGD)}

Tahap FGD melibatkan produsen abon dan panelis semi terlatih yang diambil dari lingkungan program studi teknologi pangan FTP Unud. FGD pertama dilakukan dengan produsen abon sejumlah 6 orang untuk menentukan atribut sensori yang ditonjolkan pada masing-masing produk. Data atribut sensori yang telah didapatkan didiskusikan dengan panelis semi terlatih sebanyak 8 orang yang berasal dari mahasiswa yang familiar dengan karakteristik abon dan tidak memiliki alergi terhadap produk hasil laut (Tjiptoputri, 2017). Adapun atribut yang diajukan sebelum FGD yaitu warna kecokelatan, aroma amis ikan, aroma rempah, aroma manis, tekstur butiran, tekstur berserat, tekstur kering, tekstur berminyak, rasa manis, rasa asin, rasa pedas, rasa gurih, dan rasa pahit. Adapun atribut sensori yang telah disetujui dalam FGD dengan produsen dan panelis semi terlatih sebanyak 11 atribut dengan 2 atribut yang tidak digunakan yaitu atribut tekstur butiran serta rasa pahit.

\section{Skrining Panelis}

Penelitian ini menggunakan jumlah panelis minimal 30 orang (Soewarno dan Soekarto, 1985) yang terdiri dari panelis tidak terlatih dan panelis konsumen. Panelis tidak terlatih berasal dari karyawan perusahaan dan panelis konsumen adalah target pemasaran dengan suatu kondisi tertentu. Tahap skrining panelis dilaksanakan di wilayah Denpasar, Badung, dan Universitas Udayana dengan pengisian kuisioner oleh calon panelis. Syarat menjadi target pasar produk yaitu dilihat dari ketertarikannya terhadap varian produk abon, tidak memiliki gangguan pada indera penglihatan, penciuman, dan pengecapan tidak memiliki alergi produk hasil laut, rempah-rempah, dan tidak memiliki riwayat hipertensi.

\section{Persiapan Penyajian Sampel}

Sampel abon ikan jenis pelagis besar disajikan masing-masing sebanyak $10 \mathrm{~g}$ secara monoadik untuk menghindari adanya pembandingan antar sampel. Sampel diberi kode tiga digit angka acak dan disajikan dengan urutan acak untuk menghindari bias.

\section{Pengujian Rating Hedonik dan Rate All That Apply (RATA)}

Pengujian dilakukan dengan teknik home use test karena keadaan pandemi saat ini yang membatasi pergerakan orang. Pengujian dimulai dengan penetralan indera perasa panelis dengan air mineral. Panelis mencicipi satu persatu sampel yang disajikan dan memberi penilaian terhadap sampel tanpa membandingkan. Pengujian sampel 
tidak disertai dengan produk pendamping (food carrier).

Pengujian pertama yang dilakukan oleh panelis adalah uji rating hedonik. Panelis akan menilai sampel dengan enam poin skala kesukaan (6p) yaitu sangat tidak suka, tidak suka, agak tidak suka, agak suka, suka, dan sangat suka tanpa adanya skala netral. Pengujian kedua yang dilakukan adalah uji Rate all That Apply (RATA). Uji RATA dilaksankan dengan memberi tanda ceklis/centang pada tabel pernyataan RATA untuk setiap atribut yang dianggap mendeskripsikan sampel. Atribut yang dipilih panelis akan diberikan rating intensitas sesuai persepsi panelis dengan menggunakan skala lima poin $(5 p)$ yaitu sangat rendah, rendah, sedang, tinggi, sangat tinggi.

\section{Analisis Data}

Analisis data uji RATA dan rating hedonik menggunakan software XLSTAT 2015 dan SPSS Statistics 18. Peta kesukaan dianalisis dengan PREFMAP serta identifikasi prediksi target pasar menggunakan software The Unscrambler X 10.4.

\section{Parameter yang Diamati}

Parameter yang diamati meliputi profil panelis, profil sensori produk yang disajikan dengan grafik biplot Principal Component Analysis (PCA) dimana pembandingan masingmasing atribut untuk setiap sampel menggunakan analisis sidik ragam (ANOVA) dengan uji lanjut Duncan pada taraf nyata $5 \%$, peta kesukaan panelis ditentukan dengan analisis multivariat Preference Mapping (Addinsoft, 2015) serta identifikasi target pasar dianalisis dengan teknik L-Partial Least Square Regression (L-PLSR) (Tjiptoputri, 2017 dengan modifikasi).

\section{HASIL DAN PEMBAHASAN}

\section{Profil Panelis}

Calon panelis yang mengisi kuisioner skrining sebelum pengujian sebanyak 65 orang yang terdiri dari pengisian kuisioner secara daring sebanyak 54 orang dan secara luring sebanyak 11 orang. Calon panelis yang tidak lolos skrining sebelum pengujian sebanyak 10 orang. Panelis yang mengisi kuisioner skrining bersamaan dengan pengujian sebanyak 10 orang dan semuanya lolos pada tahap skrining.

Data panelis yang dapat diolah sebanyak 65 data yang diperoleh dari panelis perempuan sebanyak 35 orang (54\%) dan laki-laki sebanyak 30 orang $(46 \%)$. Domisili panelis tersebar di daerah Denpasar sebanyak 38 orang (58\%) dan daerah Badung sebnayak 27 orang (42\%). Panelis yang mengikuti dan lolos tahap skrining berada pada rentang usia 18-30 tahun dimana usia di bawah 20 tahun sebanyak 14 orang (22\%) dan di atas 20 tahun sebanyak 51 orang (78\%). Data panelis ini akan digunakan untuk penentuan prediksi target pasar produk abon ikan jenis pelagis besar.

\section{Profil Sensori Produk Abon Ikan Jenis Pelagis Besar \\ Produk abon ikan jenis pelagis besar yang} diidentifikasi profil sensorinya pada penelitian ini yaitu produk dengan kode $\mathrm{O}, \mathrm{P}, \mathrm{Q}, \mathrm{R}, \mathrm{S}$, dan $\mathrm{T}$. Korelasi atribut abon ikan jenis pelagis besar menurut persepsi panelis dapat dilihat pada Gambar 1. 


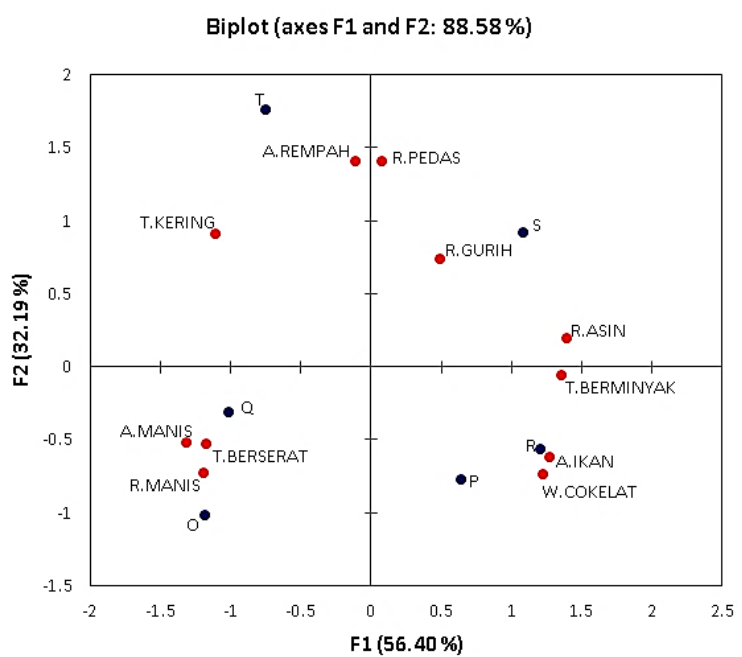

Gambar 1. Biplot PCA profil sensori produk abon ikan jenis pelagis besar (titik merah: atribut sensori; titik biru: kode sampel produk)

Sebaran dan korelasi atribut dalam bentuk positif ataupun negatif dari abon ikan jenis pelagis besar ditunjukkan dalam bentuk titik-titik dalam grafik PCA. Korelasi positif menunjukkan bahwa peningkatan ataupun penurunan intensitas atribut yang satu dengan yang lainnya akan saling mempengaruhi. Korelasi positif dapat terjadi jika posisi titik-titik atribut berdekatan dan membentuk sudut dibawah $90^{\circ}$ dari titik pusat atau berada dalam kuadran yang sama. Sebaliknya pada korelasi negatif (tidak adanya korelasi) dapat terjadi jika titik-titik atribut saling berjauhan dan membentuk sudut lebih dari $90^{\circ}$ dari titik pusat atau berada dalam kuadran berbeda. Berdasarkan Gambar 1. Atribut rasa manis (R.Manis) dipersepsikan akan mengalami peningkatan intensitas apabila salah satu atribut aroma manis (A.Manis) atau tekstur berserat (T.Berserat) mengalami peningkatan. Intensitas atribut warna kecokelatan (W.Cokelat) dipersepsikan akan meningkat jika intensitas atribut aroma amis ikan (A.Ikan) juga meningkat, sebaliknya intensitas atribut aroma rempah (A.Rempah) akan menurun jika intensitas aroma amis ikan meningkat. Hal ini juga berlaku jika intensitas rasa manis akan menurun jika intensitas rasa asin (R.Asin), dan rasa pedas (R.Pedas) meningkat. Intensitas tekstur kering (T.Kering) juga akan meningkat bila intesitas tekstur berminyak (T.Berminyak) menurun. Peningkatan serta penurunan atribut rasa gurih tidak mempengaruhi persepsi panelis terhadap intensitas atribut lainnya karena posisi titik atribut tersebut berada paling dekat dengan pusat grafik dibandingkan atribut lainnya sehingga atribut rasa gurih (R.Gurih) tidak dapat dijelaskan dengan baik oleh faktor-faktor penyusun biplot PCA. Menurut Abdi dan Williams (2010), menyatakan bahwa semakin jauh titik-titik atribut dari pusat grafik, maka faktor-faktor penyusun biplot PCA dapat menjelaskan dengan baik terkait korelasi masing-masing atribut dan berlaku sebaliknya. Hal ini diperkuat dengan atribut rasa gurih yang dijelaskan dengan baik pada faktor kedua (F2) dan faktor ketiga (F3), sedangkan atribut lainnya sudah dijelaskan dengan baik oleh faktor pertama (F1) dan faktor kedua (F2) yang dijadikan bahan pembentukan grafik.

Titik-titik atribut yang berada dalam satu kuadran dengan produk dan jaraknya berdekatan dengan membentuk sudut di bawah $90^{\circ}$ menjadi dasar dalam penentuan profil sensori produk yang ditampilkan pada Tabel 1. Produk O dipersepsikan oleh panelis memiliki profil sensori yang serupa dengan produk $\mathrm{Q}$ yakni aroma manis, tekstur berserat, dan rasa manis. Aroma manis pada umumnya berafiliasi dengan rasa manis. Senyawa organik alifatik gugus $\mathrm{OH}$ yang terkandung pada gula bebas seperti glukosa dan ribosa, aldehid, dan 
gliserol dapat mempengaruhi terbentuknya atribut rasa manis pada ikan (Okada, 1990; dalam Pratama, 2012).

Tabel 1. Profil sensori produk menurut persepsi panelis dilihat dari grafik biplot PCA

\begin{tabular}{|c|c|c|}
\hline No & Produk & Profil Sensori \\
\hline 1 & $\mathrm{O}$ & $\begin{array}{l}\text { Aroma manis, tekstur berserat, } \\
\text { rasa manis }\end{array}$ \\
\hline 2 & $\mathrm{P}$ & $\begin{array}{l}\text { Warna kecokelatan, aroma amis } \\
\text { ikan, tekstur berminyak, rasa } \\
\text { asin, }\end{array}$ \\
\hline 3 & Q & $\begin{array}{l}\text { Aroma manis, tekstur berserat, } \\
\text { rasa manis }\end{array}$ \\
\hline 4 & $\mathrm{R}$ & $\begin{array}{l}\text { Warna kecokelatan, aroma amis } \\
\text { ikan, tekstur berminyak, rasa } \\
\text { asin }\end{array}$ \\
\hline 5 & $\mathrm{~S}$ & Rasa gurih, rasa asin, rasa pedas \\
\hline 6 & $\mathrm{~T}$ & $\begin{array}{l}\text { Aroma rempah, tekstur kering, } \\
\text { rasa pedas }\end{array}$ \\
\hline
\end{tabular}

Penambahan gula pasir dalam proses pembuatan abon ikan dapat meningkatkan intensitas pada atribut sensoris aroma manis dan rasa manis yang terdeteksi oleh panelis. Tekstur berserat yang dapat dirasakan pada abon $\mathrm{O}$ dan $\mathrm{Q}$ dikarenakan serat-serat otot ikan masih terlihat dalam abon walupun ukurannya tidak sebesar pada daging hewan darat (Mouritsen O.G, 2009). Pengaturan suhu dan waktu yang tepat saat proses pembuatan abon menyebabkan serat-seratnya masih bisa dipertahankan walaupun tidak seberapa.

Produk P dipersepsikan oleh panelis memiliki profil sensori yang serupa dengan produk $\mathrm{R}$ yakni warna kecokelatan, aroma amis ikan, serta tekstur berminyak. Warna kecokelatan pekat dapat muncul karena terjadinya reaksi maillard yang merupakan sumber utama kerusakan protein selama proses pemanasan dalam pembuatan abon saat adanya kontak dengan minyak. Pada proses penggorengan abon yang menggunakan minyak akan menghasilkan tekstur abon yang berminyak jika proses penirisan tidak maksimal. Penirisan dapat dimaksimalkan dengan memanfaatkan alat bantu seperti sttirer. Aroma amis ikan yang dominan dapat muncul disebabkan oleh kandungan trimetilamin yang terdapat pada ikan jenis pelagis besar. Menurut Burdock (2005) dalam Pratama (2012), komponen trimetilamin terdeteksi sebagai komponen volatil yang menimbulkan adanya aroma amis (fishy), tajam (pungent) dan seperti ammonia. Adanya korelasi antara warna kecokelatan dengan aroma amis ikan dapat terjadi karena pengaruh dari kesegaran ikan sebagai bahan baku dalam pembuatan abon. Ikan yang kesegarannya menurun akan mengalami kerusakaan protein yang juga dapat meningkatkan pembentukan senyawa trimetiamin penyebab aroma amis pada ikan. Terpecahnya protein menjadi asam amino juga mempengaruhi kelajuan reaksi maillard. Semakin meningkat jumlah asam amino, maka semakin cepat terjadinya perubahan warna (Namiki et al, 1986; dalam R, Dedin, 2006). Aroma amis ikan yang tinggi pada produk abon ikan juga dapat disebabkan karena proses pengolahan ikan tidak dibarengi dengan perlakuan pendahuluan. Perlakuan pendahuluan yang dapat dilakukan untuk mengurangi terbentuknya aroma amis ikan yakni dengan perendaman pada air yang dicampur dengan senyawa asam alami yang terdapat pada jeruk nipis, belimbing wuluh, atau lemon yang dapat menghambat pertumbuhan bakteri penyebab kerusakan pada daging ikan.

Produk S dipersepsikan menonjolkan rasa gurih, asin, serta pedas. Adanya rasa gurih 
dihubungkan dengan senyawa asam glutamat atau garamnya seperti monosodium glutamat, inosin 5monofosfat (IMP), dan guanidin 5-monofosfat (GMP) (Winarno, 2008; dalam Pratama, 2012). Kontributor rasa paling penting dan umami yang terkandung diseluruh spesies ikan jenis pelagis besar disebabkan oleh asam glutamat bebas serta terutama IMP (Yamaguchi \& Watanabe, 1990; dalam Pratama, 2012). Adanya rasa asin dihubungkan dengan penggunaan garam-garam anorganik seperti $\mathrm{NaCl}$ dalam prosen pembuatan abon. Menurut Sebranek (2009), natrium tidak saja memberikan rasa asin, namun keberadannya mampu meningkatkan intensitas dari flavor lain (Pratama, 2012). Adanya penambahan garam serta kandungan alami senyawa kimia dari ikan jenis pelagis besar yang hidup di lautan membuat rasa asinnya sangat kuat dirasakan oleh panelis.

Produk T dipersepsikan menonjolkan tekstur kering, aroma rempah, serta rasa pedas. Tekstur kering yang dimiliki oleh produk $\mathrm{T}$ disebabkan oleh adanya proses pengurangan kadar air pada ikan sebelum dilakukan proses penggorengan dan dikombinasikan dengan penirisan yang dilakukan secara maksimal. Adanya aroma rempah yang dirasakan oleh panelis berasal dari penambahan berbagai jenis bumbu pada pembuatan abon sehingga mempengaruhi aroma serta rasanya. Kandungan minyak volatil pada rempah-rempah akan menghasilkan senyawa aromatik yang berkontribusi besar pada pembentukan flavor. Menurut Brown (2009), kesan aroma yang tajam menusuk, panas, manis atau pahit berasal dari minyak nonvolatil (oleoresin) pada rempahrempah. Kemunculan rasa pedas pada abon $\mathrm{T}$ berhubungan erat dengan penggunanaan rempahrempah seperti lada dan cabai yang mengandung senyawa capsaicin.

Berdasarkan hasil analisis sidik ragam (ANOVA) dengan uji lanjut Duncan pada taraf 5\%, beberapa atribut sensori memiliki signifikansi yang berbeda pada profil sensori produk yang memiliki kemiripan yang dapat dilihat pada Gambar 2.

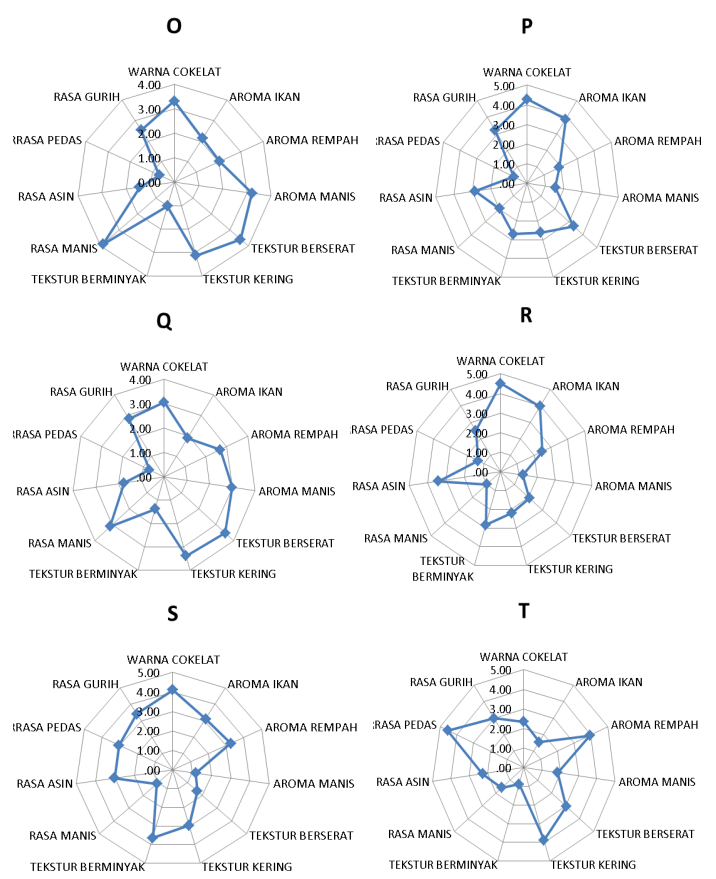

Gambar 2. Grafik spiderweb profil sensori masingmasing produk abon ikan jenis pelagis besar

Berdasarkan persepsi panelis pada Gambar 2. produk $\mathrm{O}$ memiliki profil sensoris serupa dengan produk Q. Gambar 2 menunjukkan bahwa produk $\mathrm{O}$ berbeda nyata dengan produk $\mathrm{Q}$ pada atribut rasa manis, dimana produk $\mathrm{O}$ dipersepsikan memiliki intensitas rasa manis yang lebih tinggi dibandingkan dengan Q. Berdasarkan persepsi panelis, produk $\mathrm{P}$ memiliki profil sensoris serupa dengan produk R. Gambar 2. menunjukkan bahwa produk $\mathrm{P}$ berbeda nyata dengan produk $\mathrm{R}$ pada atribut rasa asin dan warna kecokelatan, dimana produk $\mathrm{P}$ memiliki intensitas rasa asin dan warna 
kecoklatan yang lebih rendah dibandingkan dengan R.

Profil sensori produk S dan T tidak memiliki nilai profil sensoris yang sama dibandingkan dengan produk abon lainnya. Berdasarkan Gambar 2. pada spiderweb terlihat jika produk S memiliki intensitas atribut sensori rasa gurih tertinggi dengan kriteria sedang yang tidak berbeda dengan produk $\mathrm{P}$ namun berbeda signifikan dengan produk T. Produk $\mathrm{S}$ juga memiliki intensitas rasa asin dengan kriteria sedang yang tidak berbeda dengan produk $\mathrm{P}$, namun berbeda signifikan dengan produk T. Produk S memililki intensitas rasa pedas dengan kriteria sedang, akan tetapi nilai intensitas rasa pedas pada produk $\mathrm{S}$ lebih rendah dibandingkan intensitas produk $\mathrm{T}$ dengan kriteria tinggi

\section{Peta Kesukaan Panelis terhadap Produk Abon Ikan Jenis Pelagis Besar}

Analisis PREFMAP (preference mapping) digunakan dalam pembuatan peta kesukaan panelis terhadap produk yang ditampilkan dalam bentuk grafik contour plot. Grafik contour plot pada Gambar 3. memiliki lima zona daerah yang menjelaskan presentase jumlah panelis yang memberikan nilai kesukaan di atas rata-rata terhadap atribut sensori dan produk abon. Zona daerah tersebut dibagi dalam beberapa warna yaitu zona merah berada pada rentang $80-100 \%$, zona kuning berada pada rentang $60-80 \%$, zona hijau berada pada rentang $40-60 \%$, zona biru muda berada pada rentang $20-40 \%$, dan zona biru tua berada pada rentang 0-20\%. Grafik biplot PCA bisa dapat disatukan dengan contour plot untuk mendapatkan informasi terkait atribut dan produk yang dikehendaki oleh panelis.

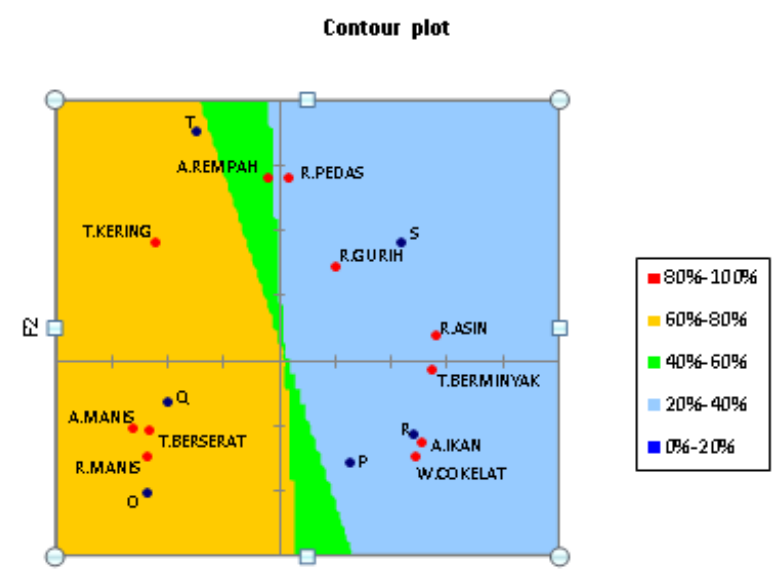

Gambar 3. Contour plot preference mapping produk abon ikan jenis pelagis besar (titik merah: atribut sensori; titik biru: kode sampel produk)

Hasil analisis PREFMAP menunjukkan bahwa $78 \%$ panelis memberikan nilai kesukaan di atas rata-rata pada produk Q dan $67 \%$ panelis memberikan nilai kesukaan di atas-rata-rata pada produk $\mathrm{O}$ dan $\mathrm{T}$, sehingga produk $\mathrm{O}, \mathrm{Q}$, dan $\mathrm{T}$ berada pada zona kuning (60-80\%). Produk P, R, dan $\mathrm{S}$ mendapatkan nilai kesukaan di atas rata-rata dari 33\% panelis yang berarti produk tersebut terletak pada zona biru muda (20-40\%). Hal ini menujukkan bahwa tidak terdapat produk yang tidak disukai oleh panelis. Berdasarkan Lampiran 4, Produk yang disukai panelis adalah produk Q dengan kriteria sangat suka yang tidak berbeda nyata dengan produk $\mathrm{O}$ dengan kriteria sangat suka. Produk $\mathrm{T}$ dengan kriteria suka yang tidak berbeda nyata dengan produk P. Produk R memiliki tingkat kesukaan terendah dengan kriteria suka yang tidak berbeda nyata dengan produk S. Atribut yang dikehendaki oleh panelis berdasarkan sebaran atribut pada contour plot dilihat dari zona kuning sampai hijau yaitu, aroma manis, aroma rempah, tekstur berserat, tekstur kering, dan rasa 
manis. Atribut yang kurang dikehendaki jika intensitasnya terlalu tinggi yang masuk dalam zona biru muda yaitu rasa asin, tekstur berminyak, aroma amis ikan, warna kecokelatan, rasa gurih, dan rasa pedas.

Produk O dan Q yang memiliki profil sensori serupa yaitu aroma manis, tekstur berserat dan rasa manis memiliki kecenderungan untuk lebih disukai panelis dibandingkan dengan produk lainnya. Hal ini terjadi karena profil produk tersebut merupakan representatif dari produk abon dengan bahan dasar dari daging hewan berkaki dua atau berkaki empat yang sudah biasa dikonsumsi oleh panelis. Produk $\mathrm{T}$ yang memiliki atribut tekstur kering dan beraroma rempah juga disukai oleh panelis karena atribut tersebut terdapat pada varian abon dari daging hewan.

Rasa gurih yang seharusnya disukai panelis namun berdasarkan contour plot letaknya pada zona biru muda (kurang disukai) karena produk abon dengan rasa gurih yang tinggi dimiliki oleh produk S yang disertai dengan atribut tekstur berminyak dan rasa asin yang cukup tinggi sehingga rasa gurih tertutupi dengan kelemahan atribut lainnya yang kurang dikehendaki panelis. Intenstitas warna kecokelatan yang terlalu tinggi diasosiasikan oleh panelis dengan atribut aroma amis ikan yang juga tinggi sehingga atribut tersebut kurang dikehendaki oleh panelis. Hal ini dapat dikaitkan dengan food neophobia yang berarti ketakutan/ketidaksukaan terhadap karakter asing pada produk pangan baru.

Capiola dan Raudenbush (2012) menyatakan bahwa adanya fenomena food neophobia yang merupakan suatu reaksi alami pada manusia dalam melindungi dirinya dengan tidak mengonsumsi suatu produk pangan yang tidak dikenal atribut sensorinya. Faktor-faktor yang mempengaruhi fenomena food neopobhia antara lain umur, jenis kelamin, tingkat pendidikan, kebudayaan pada daerah tertentu, keinginan dan persepsi yang diharapkan dalam mencoba produk baru (Tuorila et al. 2001, Flight et al. 2003; dalam Muhammad et al. 2015). Menurut King et. al (2008), food neophobia akan memberikan pengaruh pada tingkat kesukaan konsumen pada produk pangan baru.

Hasil dari food neophobia terlihat pada produk $\mathrm{P}, \mathrm{R}$, dan $\mathrm{S}$ yang memiliki nilai preference mapping lebih rendah dari produk $\mathrm{O}, \mathrm{Q}$, dan $\mathrm{T}$. Atribut yang ada pada produk $\mathrm{P}, \mathrm{R}$, dan $\mathrm{S}$ yaitu tekstur berminyak, rasa asin, dan aroma amis ikan merupakan atribut yang kurang familiar pada abon yang biasa dikonsumsi sebagian besar panelis. Persepsi panelis terhadap produk yang tak sesuai dengan harapannya akan mempengaruhi kecenderungan dalam kesukaan pada suatu produk (Sorensen et al, 2003; dalam Prayoga, 2018). Adapun cara untuk meningkatkan nilai kesukaan pada produk $\mathrm{P}, \mathrm{R}$, dan $\mathrm{S}$ yaitu dengan mengatur kembali cara produksi produk agar mengurangi tekstur berminyak dan aroma amis ikan. Tektur berminyak dapat dikurangi dengan penggunaan alat peniris minyak serta aroma amis ikan dapat dikurangi dengan perlakuan pendahulun pada bahan baku. Selain perbaikan teknik produksi adapun cara lain untuk meningkatkan nilai kesukaan suatu produk pangan dengan cara pemberian label khusus. Menurut Wansink et al (2005), bahwa diperlukannya pemberian label 
informasi unik (trivia) seperti cara konsumsi produk dengan menggunakan bahan pendamping lainnya sehingga persepsi konsumen terhadap rasa produk menjadi lebih baik terutama dalam pengonsumsian abon dengan cita rasa asin, pedas, dan gurih.

\section{Identifikasi Target Pasar Produk Abon Ikan Jenis Pelagis Besar}

Penentuan target pasar produk abon ikan jenis pelagis besar memerlukan data latar belakang panelis, profil sensori produk dan nilai kesukaan panelis. Peta prediksi target pasar didapat dari hasil analisis L-Partial Least Square Regression (LPLSR). Titik-titik pada Gambar 4 yang berwarna merah (panelis), warna biru tua (atribut sensori produk), warna biru muda (kode produk), dan warna hijau (latar belakang panelis) menjadi penanda dalam pembacaan grafik L-PLSR. Latar belakang panelis yang digunakan dalam analisis LPLSR adalah dari domisili, jenis kelamin, dan rentang umur saat ini. Gambar 4 menunjukkan hasil analisis L-PLSR untuk penentuan prediksi target pasar.

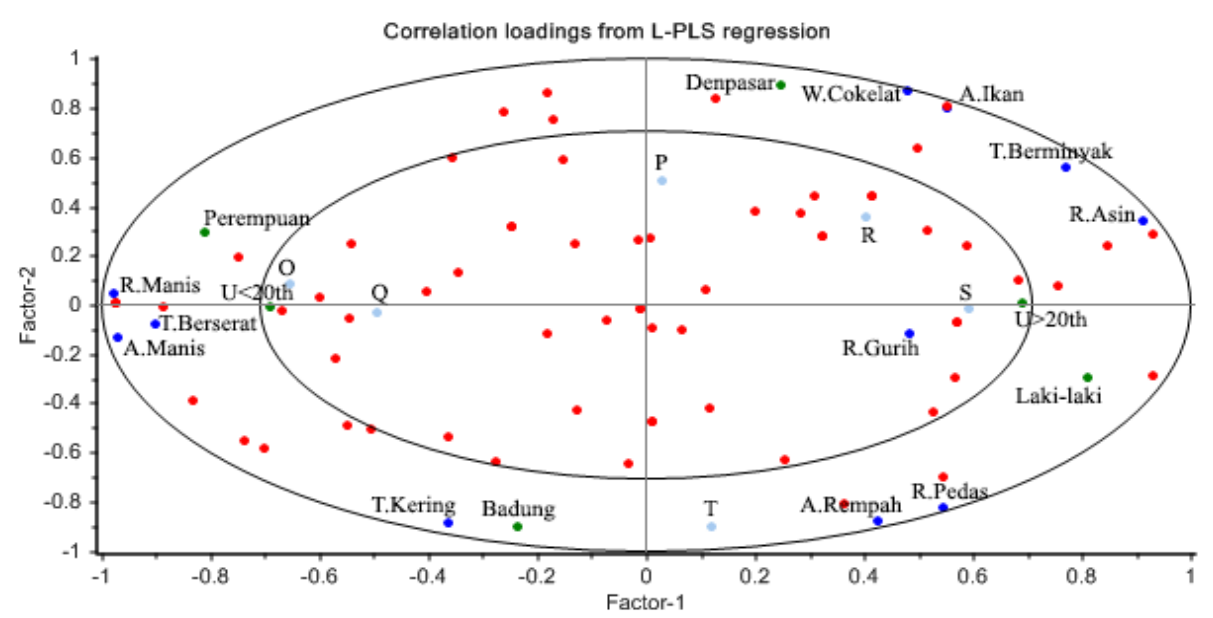

Gambar 4. Grafik L-PLSR produk abon ikan jenis pelagis besar (titik biru: atribut sensori; titik biru muda: kode sampel produk; titik hijau: kategori panelis; titik merah: panelis)

Gambar 4 pada atribut sensori rasa gurih tidak berpengaruh secara signifikan terhadap preferensi konsumen. Menurut Tenenhaus et al. (2005) dalam Prayoga (2018), adanya dua lingkaran korelasi pada grafik L-PLSR akan mempengaruhi preferensi panelis terhadap suatu produk baik berpengaruh secara signifikan atau tidak. Karakteristik produk dan latar belakang panelis yang terletak di dalam lingkaran bagian dalam tidak berpengaruh secara signifikan terhadap preferensi panelis, sedangkan jika terletak di dalam lingkaran bagian luar akan berpengaruh secara signifikan.

Produk O dan Q yang memiliki atribut aroma manis, rasa manis, dan tekstur berserat cenderung disukai oleh panelis perempuan dan panelis dengan usia kurang dari 20 tahun. Produk S yang memiliki atribut rasa gurih dan produk $\mathrm{T}$ yang memiliki atribut aroma rempah dan rasa pedas cenderung disukai oleh panelis laki-laki dan hanya produk $\mathrm{S}$ yang disukai oleh panelis dengan usia lebih dari 20 tahun. Jika dilihat dari posisi titik panelis 
perempuan dan laki-laki yang terletak di dalam lingkaran bagian luar grafik L-PLSR, kesukaan terhadap produk berpengaruh secara signifikan terhadap preferensi panelis berdasarkan jenis kelamin. Panelis perempuan cenderung menyukai produk abon dengan atribut yang mirip pada abon berbahan dasar ayam, sapi dan babi, sedangkan panelis laki-laki cenderung menyukai produk abon dengan atribut sensori yang jarang ditemui sebelumnya. Hal ini dapat terjadi karena adanya fenomena food neophobia (keadaan individu yang enggan mencoba produk baru) dan food neofilia (keadaan individu yang berkeinginan mencoba produk baru) yang dipengaruhi oleh faktor psikologi dan bawaan genetik (Capiola dan Raudenbush, 2012). Jika dilihat dari posisi titik panelis usia di bawah dan di atas 20 tahun yang terletak di dalam lingkaran bagian dalam grafik LPLSR, kesukaan terhadap produk tidak berpengaruh secara signifikan terhadap preferensi panelis berdasarkan rentang usia.

Panelis yang berdomisili di Denpasar cenderung menyukai produk $\mathrm{P}$ dan $\mathrm{R}$ dengan atribut warna kecokelatan dan aroma amis ikan, sedangkan panelis yang berdomisili di Badung cenderung menyukai atribut kering dan menyukai produk Q. Hal ini dapat terjadi karena panelis yang berdomisili di Denpasar menganggap bahwa abon ikan memang harus memiliki warna kecokelatan yang pekat dengan aroma amis ikan di dalam produk tersebut sehingga dapat dipercayai bahwa abon tersebut memang menggunakan bahan baku ikan. Pergerakkan yang dinamis pada perputaran barang dan jasa di perkotaan seperti kota Denpasar menyebabkan produk baru muncul lebih cepat.
Calon konsumen nantinya akan memiliki rasa penasaran untuk mencoba produk baru dan memahami adanya berbagai varian rasa pada produk-produk baru tersebut (Flight et al, 2003; dalam Prayoga, 2018). Panelis berdomisili di Badung cenderung menyukai produk abon dengan tekstur kering dikarenakan produk yang biasa mereka temui selalu memiliki ciri khas berupa tekstur kering yang tahan lama pada abon manapun yang mereka konsumsi. Penelitian oleh Sorensen et al, (2003); dalam Prayoga, (2018) menyatakan bahwa persepsi panelis terhadap produk yang tak sesuai dengan harapannya akan mempengaruhi kecenderungan dalam kesukaan pada suatu produk sehingga abon yang intensitas tekstur keringnya rendah kurang disukai oleh panelis yang mengharapkan hal tersebut.

\section{KESIMPULAN}

Kesimpulan yang didapat berdasarkan hasil penelitian yaitu produk $\mathrm{O}$ dan $\mathrm{Q}$ memiliki profil sensori aroma manis, tekstur berserat, dan rasa manis. Produk P memiliki profil sensori warna kecokelatan, aroma ikan, tekstur berserat, rasa asin dan rasa gurih. Produk R memiliki profil sensori warna kecokelatan, aroma ikan, dan rasa asin. Produk S memiliki profil sensori tekstur berminyak, rasa asin, rasa pedas, dan rasa gurih. Produk T memiliki profil sensori tekstur kering, aroma rempah, dan rasa pedas. Peta kesukaan konsumen menunjukkan bahwa produk Q memiliki tingkat kesukaan tertinggi, lalu diikuti produk $\mathrm{O}$ dan $\mathrm{T}$, dan yang terakhir adalah produk $\mathrm{P}, \mathrm{R}, \mathrm{S}$, dimana atribut sensori yang disukai panelis yaitu 
aroma manis, aroma rempah, tekstur berserat, tekstur kering, serta rasa manis.

\section{DAFTAR PUSTAKA}

Abdi H, Williams LJ. 2010. Principal component analysis. WIREs Computational Statistics. 2: 433-459.

Addinsoft. 2015. Preference mapping (PREFMAP).

https://www.xlstat.com/en/solutions/features/ preferencemapping. Diakses tanggal 1 Juni 2020.

Anonimus. 2020. Daftar usaha abon ikan pada marketplace Tokopedia di areal Denpasar. https://www.tokopedia.com/search?q=abon+ ikan+denpasar. Diakses Juli 2020

BBPPPKP (Balai Besar Pengujian Penerapan Produk Kelautan dan Perikanan). 2019. Nilai dan Volume Ekspor Tuna, Cakalang, Tongkol Januari-Maret (Triwulan I) Tahun 2019 Mengalami Kenaikan. Jakarta

BPOM (Badan Pengawas Obat dan Makanan). 1995. SNI 01-3707-1995 Abon. Jakarta.

Brown, J.J. 2009. Spices, seasonings and flavors ingredients in meat products. New York: Springer Science

Burdock, A.G. 2005. Fenaroli's handbook of flavor ingredients fifth edition. Boca Raton: CRC Press

Capiola A, Raudenbush B. 2012. The Effects of Food Neophobia and Food Neophilia on Diet and Metabolic Processing. Food and Nutrition Sciences. 3(2012): 1397-1403.

Dinas Koperasi dan UMKM Kabupaten Badung. 2019. Data pengusaha makanan dan minuman dengan izin p-irt. Bali

Dinas Koperasi dan UMKM Kota Denpasar 2019. Data pengusaha makanan dan miniman dengan izin p-irt. BaliJaeger, SR dan Ares, G. 2015. RATA Questions are not likely to Bias Hedonic Scores. Food Quality and Preference. 44 (2015): 157-161.

Flight, Ingrid., P. Leppard, C. David N. 2003. Food neophobia and associations with cultural diversity and socio-economic status amongst rural and urban australian adolescents. J. Appetite. 41: 51-59

Kementerian Koperasi dan MKM. 2018. Perkembangan Data Usaha Mikro, Kecil, Menengah (UMKM) dan Usaha Besar (UB) Tahun 2017-2018. Jakarta
King SC, Meiselman HL, Henriques A. 2008. The Effect of Choice and Psychographics on the Acceptability of Novel Flavors. Food Quality and Preference. 19:692696.

McPherson G. 2011. Applying and Interpreting Statistics: A Comprehensive Guide. New York (US): Springer-Verlag

Meyners, M., Jaeger, SR., Ares, G. 2016. On the Analysis of Rate-All-That-Apply (RATA) Data. Food Quality and Preference. 49(2016): 1-10.

Mouritsen O.G. 2009. The molecules of life. In: SUSHI Food for the eye, the body \& the soul. Boston: Springer

Muhammad R, Abudllah KM, Zahari MSM, Sharif MSM. 2015. Revealing the Scenario of Food Neophobia among Higher Learning Institution Students from Klang Valley, Malaysia. Procedia-Social and Behavioral Sciences. 170:292-299

Okada, M. 1990. Fish as raw material of fishery products. In Motohiro, T., Kadota, H., Hashimoto, K., Kayama, M., and Tokunaga, T. (eds). Science of Processing Marine Products. 1: 1-15.

Pratama, Rusky Intan. 2012. Karakteristik Sensori Beberapa Produk Ikan Asap Khas Daerah Di Indonesia Dengan Menggunakan Metode Quantitative Descriptive Analysis. JPB Perikanan Vol. 7 No. 2 Tahun 2012: 117-130. Institut Pertanian Bogor

Prayoga, Aditya. 2018. Evaluasi Profil Sensori Minuman Serbuk Instan Rasa Jeruk Menggunakan Metode Rate-All-That-Apply (RATA). Skripsi. Bogor: IPB

R, Dedin F., Fardiaz, Dedi., dan Apriyantono, Anton. 2006. Isolasi dan Karakterisasi Melanoidin Kecap dan Peranannya sebagai Antioksidan. Jurnal Teknologi dan Industri Pangan Vol XVII no. 3 (2006): 204-213.

Reinbach HC, Giacalone D, Ribeiro LM, Bredie WLP, Frost MB. 2014. Comparison of three sensory profiling methods based on consumer perception: CATA, CATA with intensity, and mapping. Food Quality and Preference. 32(2014): 160-166.

Sebranek, J. 2009. Basic curing ingredients. In Tarte, R. (ed.). Ingredients in Meat Product. Properties, Functionality and Applications. Springer Science, New York. p. 1-24.

Sorensen, LB, P. Moller, A. Flint, M. Martens, A. Raben. 2003. Effect of sensory perception of foods on appetite and food intake: a review of 
studies on humans. International Journal of Obesity. 27: 1152-1166.

Tenenhaus, M., J. Pages, L. Ambroisine, C. Guinot. 2005. PLS methodology to study relationships between hedonic judgements and product characteristics. Food Quality and Preference. 16: 315-325.

Tjiptoputri, Olivia Mellyana. 2017. Evaluasi Profil Sensori Sediaan Pemanis dengan Metode Rate-All-That-Apply (RATA). Skripsi. Bogor: IPB

Tuorila H, Lahteenamki L, Phjalainen L, Lotti L. 2001. Food neophobia among the Finns and related responses to familiar and unfamiliar foods. Food Quality and Preference. 12:2937.

Utami, Dyah putri. 2019. Perubahan Karakteristik Ikan Nilem pada Berbagai Pengolahan Suhu Tinggi. Jurnal Perikanan dan Kelautan vol. X no. 1 / Juni 2019 (39-45). Unversitas Padjajaran

Wansink, B., Van Ittersum, K., Painter, JE. 2005. How descriptive food names bias sensory perceptions in restaurants. Food Quality and Preference. 16(5):393400.

Winarno, F.G. 2008. Kimia Pangan dan Gizi. Bogor. M-Brio Press. 